\begin{abstract}
Владимир
Градев

\section{Confessio philosophi}

Конечно, нештата што накострешуваат [...] Ме принудија да мислам на Бог. В. Х. Оден, Благодарница
\end{abstract}

Во оваа „исповед“ би сакал да ѝ дадам некаков облик на мојата „потрага“, не со премолчување на она за кое не можам да зборувам, туку обидувајќи се да го кажам она за кое не можам да молчам. Добро е позната тезата која го претпоставува и нагласува антагонизмот меѓ христијанството и модерноста и која ја разбира постмодерноста преку призмата на „Смртта на Бог“. Според апологетите на христијанството, модерноста е антирелигиска затоа што го доведува револтот кон Бог до неговите граници, односно до некаков раб. Ова е начинот на кој односите меѓу религијата и модерноста најчесто се сведуваат единствено на нивното заемно исклучување. Религијата има антимодерна тензија до онаа мера до која просветителството го отфрла авторитетот на откровението и на традицијата, до мерата до која воспоставувањето на едно демократско општество директно го оспорува принципот на хиерархија на едно црковно општество. Бескомпромисниот фундаментализам реагира на овие тврдења на модерноста, коишто се чинат доста богохулни. Но, истовремено, гледаме дека секуларизацијата не мора нужно да се поистовети со атеизмот, дека слободата на свеста не ги компро-

\section{Vladimir Gradev}

\section{Confessio philosophi}

Finally, hair-raising things [...] Forced me to think about God. W.H. Auden, A Thanksgiving

In this "confession" I will try to give some shape to my "quest" not by keeping silent of what I cannot speak about, but trying to say that of what I cannot keep silent. Well known is the thesis that suggests and stresses the antagonism between Christianity and modernity and that comprehends postmodernity through the prism of the "Death of God." According to the apologists of Christianity, modernity is anti-religious because it brings the revolt against God to its limits, that is to say, to an edge. That is how the relations between religion and modernity are most often reduced solely to their mutual exclusion. Religion has an anti-modern tension as far as the Enlightenment deposes the authority of revelation and tradition, as far as the establishment of a democratic society directly denies the hierarchy principle of a church-society. The uncompromising fundamentalism reacts to these, namely, claims of modernity, which seem to be rather sacrilegious. But at the same time we see that secularization does not have necessarily to be identified with atheism, that freedom of consciousness does not compromise the truth claims of religion and that the separation of church and state is the best guarantee for the preservation of faith. 
митира религиските тврдења за вистинитост и дека одвојувањето на црквата и државата е најдобрата гаранција за зачувување на верата.

Философската пресвртница на постмодерната култура се должи на кризата на просветителскиот разум. Низ минатиот век овој разум се покажа неспособен да го отстрани или барем да го филтрира уништувачкиот нагон. Тој веќе, се чини, не е способен да ги преиспита сопствените вредности, да измисли нови патишта и цели. Кризата не наликува на привремена појава, затоа што ја допира суштината на самиот разум: тој осознава дека ја загубил својата основа. Денес „слабата“ мисла на постмодернизмот се обидува да ја ублажи болката од загубата, да ги доведе до задоволителен крај чиновите на оплакување и прежалување, отаде конфликтите и насилството, отаде поразот и страдањето.

По добата на сомнеж, философската култура на сегашноста се расејува во низа „зајдисонца“: она на вистината, на субјектот, на битието. Вистината се претвора во симулакрум, субјектот се губи себеси во разновидност и безначајност (Музиловиот Mann ohne Eigenschaften), битието се распрснува во низа маски, кои не кријат ништо. По ослабувањето на позитивизмот, секоја рефлексивна метода која се однесува на философијата, како и секој вид антропологија заснована на човечката суштина, е деконструирана.

Постмодернизмот го осознава фактот дека разумот, обидувајќ́ се да го покори трансцедентното за време на просветителството, се има исцрпено. Се соочуваме со помрачување на разумот. Постмодерноста, преплавена од малите нарации, не ги вреднува премногу ниту минатото, ниту иднината. Таа се концентрира во срцето на сегашноста, сегашност затворена
The philosophical turn of post-modern culture is due to the crisis of the Enlightenment reason. Throughout the past century this reason has turned out to be incapable of removing or just even filtering the destructive drive. It does not seem anymore to be in a condition to revise its values, to invent new ways and goals. The crisis does not look as a temporal occurrence, because it touches the essence of the sole reason: it realizes it has lost its fundament. Nowadays the "weak" thought of postmodernism tries to anaesthetize the pain of loss, to bring to a satisfactory ending the acts of mourning, beyond conflicts and violence, beyond defeat and suffering.

After the age of suspicion the philosophic culture of the present is scattering into a series of "sunsets": the one of the truth, the subject, the being. Truth is turning into simulacrum, the subject loses itself in diversity and unimportance (Musil's Mann ohne Eigenschaften), being is spreading as a series of masks, hiding nothing. After the decline of positivism every method of reflection referring to philosophy as well as every kind of anthropology based on the essence of humanity is being deconstructed.

Postmodernism realizes the fact that reason, trying to conquer the Transcendent during the Enlightenment, has been exhausted. We are facing reason becoming obscure. Postmodernity, overwhelmed by the small narratives, does not give much value, neither to the past nor to the future. It is concentrating itself into the heart of the present, a present closed for the utopian spirit, 
за утопистичкиот дух, без метафизичка анксиозност и утеха, без религиски страв и трепет.

Философијата за време на првите 1500 години од христијанската ера е дефинирана како ancilla theologiae и служела за подготовка на теренот за повозвишените спекулации на теологијата. Во модернатадоба оваа иста философија се кренала против теологијата и така станала самосуверена. Истава философија, сепак, во текот на минатиот век открива дека нема подлога или поточно дека се темели на ништо. Неопходно е денес да го земеме предвид фактот дека, во ерата на глобализацијата, живееме колебајќи се меѓу популарната резигнирана рамнодушности враќањето на фундаментализмите, кои се манифестираат преку беспомошни облици на отфрлање на технологиите или преку монструозни програми за уништување, и во однос на кои секој облик на медијација се чини беспомошен. Вклучувајќки ја тука и философијата, која е сведена на осознавањето на безначајноста на основните вредности. Кога не постои разлика помеѓу праведното и неправедното и сѐ се потпира врз критериумите на нашата толеранција, тогаш философијата е сведена само на изумување психолошки сурогати на концептуалниот и теориски вакуум.

Соочувајќ́ се со трагедијата на смислата и загубата на фундаменталните вредности, откриваме дека сега и на философијата ѝ е потребно нешто што ќе ѝ служи, за да помогне да ѝ се вратат нејзините сопствени смисла и облик. Откриваме дека на философијата ѝ е потребна теологијата, тоа грдо мало џуџе. Откриваме дека денес теологијата е повикана да ѝ стане слугинка на философијата. Одмазда на историјата? Измама на разумот? Триумф на знаењето над верата? Претпоставувам дека не. Нашата постмодерна ера не е време на трикови, лесни победи и триумфирања: таа е време на беда, алузии и тајни. without metaphysical anxiety and consolation, without religious fear and trepidation.

Philosophy during the first 1500 years of the Christian era was defined as ancilla theologiae and served the task of preparing the ground for the higher speculations of theology. In the modern era this very same philosophy rose against theology and thus became self-sovereign. The same philosophy however during the last century discovered that it has no grounds or rather that it is based on nothing. It is necessary today that we take into account the fact that in the era of globalization we live wavering between the popular resigning indifference and the return of fundamentalisms which are manifest in helpless forms of rejecting technologies or in monstrous programmes for destruction and towards which any form of mediation looks helpless. Including philosophy, which is reduced to realizing the insignificance of basic values. When there is no difference between just and unjust and everything relies on the criteria of our tolerance, then philosophy is brought to the sole invention of psychological surrogates of the conceptual and theoretical vacuum.

Facing the tragedy of sense and loss of fundamental values we find out that philosophy in its turn needs something to serve it, to help give it back its own sense and aspect. We find out that philosophy needs theology, that ugly little dwarf. We find out that theology is called up today to become a servant to philosophy. Vendetta of history? Wile of reason? Triumph of knowledge over faith? I guess not. Our post-modern era is not a time for tricks, easy victories and triumphalisms: it is a time for misery, allusions and secrets. 
Мислам дека новиот однос меѓу философијата и теологијата најдобро се опишува преку славната парабола на Валтер Бенјамин (Walter Benjamin). Некоја машина секогаш победувала во партијата шах, што ја играла на големо задоволство и радост на публиката. Но таа не ги смислувала потезите самата. Таа нив само ги извршувала. Зад машината било скриено едно грдо грбаво џуџе кое всушност ги смислувало потезите и ѝ ги пренесувало на машината. Машината го претставува историскиот материјализам, односно философијата во својата екстремна секуларизирана форма, а џуџето е теологијата, која е непримерно грда и одвратна и затоа мора да остане скриена, иако се покажува дека таа е единственото нешто способно да ја оживее философијата. Параболата на Бенјамин би можела да ги насмевне големите философи, но таа не е само провокативна - таа е исто така и многу сериозна. Таа е безмилосна кон вештите експерти кои живеат со илузијата дека светот самиот се придвижува себеси. Таа е безмилосна кон удобноста на философите во фотелји, кои застануваат зад - за нив толку драгоцената - машина на академската философија. Но, за да функционира исправно, на машината на философијата ѝ е потребно едно грдо и грбаво, но апсолутно неопходно џуџе, скриено во неа. Еве ја денешната тензија на концептот: како и со која сила можеме да зачуваме каква и да е човечка смисла и значење во философскиот факт?

Бегајќи од „трагедијата на бесмислицата“ многумина бараат прибежиште во сѐ попривлечната апофатска теологија - мистеријата на повлекувањето на Севишниот, на Божјиот молк. Сепак, по 11-ти септември, заедно со ритуалното жртвување на терористите, религиозните одеднаш повторно се вратија на светската сцена: луѓето кои ги планираа и ги започнаа терористичките напади, всушност, во тоа го препознаваат Божјиот гнев кој ја казнува престолни-
I think the new relation between philosophy and theology is best described by the famous parable of Walter Benjamin. A machine always won the chess games it played to the great pleasure and amusement of the public. But it did not play its moves by itself. It just executed them. Behind the machine was hidden an ugly hunchbacked dwarf who actually thought out the moves and passed them on to the machine. The machine represents historical materialism, that is, philosophy in its extreme secularized form, while the dwarf is theology, which is improper, ugly, and repulsive and so must remain hidden, though it turns out to be the only thing capable of reviving philosophy. Benjamin's parable may provoke a smile among great philosophers, but it is not just provocative - it is very serious as well. It is merciless for the skilled experts who live with the illusion that the world goes on by itself. It is merciless for the comfort of the chair philosophers, who stand behind the so-preciousfor-them machine of academic philosophy. But in order to function properly the philosophy machine needs an ugly and hunchbacked, but absolutely necessary, dwarf hidden inside it. Here is today's tension of the concept: how and by using what power can we save any human sense and meaning in the philosophical fact?

Escaping the "tragedy of nonsense" many look for a refuge in the more and more fashionable apophatic theology - the mystery of withdrawal of the Almighty, of God's silence. Nevertheless after September $11^{\text {th }}$ together with the ritual sacrifice of the terrorists the religious has again suddenly returned onto the world stage: the people that planned and launched the terrorist attacks actually recognize in that God's anger punishing the capital of Evil and the ones that felt victims of these attacks inevitably 
ната на Злото, а оние кои се почувствуваа како жртви на овие напади неизбежно помислија на Апокалипсата; на големата сличност меѓу падот на Вавилон и уништувањето на Менхетен. Но, ние немаме на ум некаков судир на цивилизации. Принципот: $c u-$ jus regio ejus religio веќе не важи; религиите не се ограничени во стриктни и јасно одредени граници. Теророт е глобален и стравот од хаос, огорченоста, желбата за одмазда и правда, како и за враќање на редот, за миг го досегна секој агол од планетата. Не само што Америка е денес во Азија, туку и Азија е во Америка и Европа. Исламот можеда се најде во модерното секуларизирано општество, на ист начин како што секуларизацијата е во исламот, не систематски, но одвреме навреме, периодично, совпаѓајќи се со секој конкретен излив на насилство. Се работи за непосредното насилство на светото, така што немаме на ум некој вид на посредување, формирање и конфликт меѓу одделни и добродефинирани и исцртани цивилизации, меѓу внатре и надвор, меѓу нас и нив. На изненадувачки начин религиозните прилагодувања продолжуваат да го обликуваат современиот живот, тие го преминуваат хоризонтално целиот глобализирачки свет, каде што кризата воопшто не го поштедува светот на либералната демократија. Крајот на историјата, објавен од Фукујама веднаш по 1989 год., се покажа како ера на радикализирачка тензија и конфликт. Добро е познато дека западниот свет е роден во долгиот процес на секуларизација. Она што навистина изненадува, меѓутоа, е дека религијата продолжува да го поларизира. Конфликтот меѓу религијата и општеството се поместува од стриктно политичката сфера (односите помеѓу црквата и државата) кон сферата на етиката и на правото (судирот околу абортусот, евтаназијата и генетските манипулации се случува меѓу поборниците на науката и технологијата и новите крстонос- thought of the Apocalypse; the sharp semblance between the fall of Babylon and the Manhattan destruction. But we do not have in mind a civilization conflict. The principle, cujus regio ejus religio is not valid anymore; the religions are not limited within strict and clearly defined borders. Terror is global and the fear of chaos, the resentment, the lust for revenge and justice and restitution of order in no time run through every corner of the planet. Not only is America in Asia today, but Asia is in America and Europe as well. Islam is to be found in modern secularized society in the same manner as secularization is in Islam, not systematically, but on and off, episodically, punctual with every concrete outbreak of violence. It has to do with the immediate violence of the sacred, so we do not have in mind any kind of mediation, formation and conflict between distinct and well-defined and outlined civilizations, between in and out, between us and them. In a surprising manner the religious adjustments continue to form contemporary life, they cross horizontally the whole globalizing world where the crisis does not spare the world of liberal democracy at all. The end of history proclaimed by Fukuyama right after 1989 turned out to be an era of radicalizing tension and conflict. It is well known that the western world was born out of the long process of secularization. What is really surprising though is that religion keeps polarizing it. The conflict between religion and society shifts from the strictly political sphere (the relations between church and state) towards the sphere of ethics and law (the collision happens between the champions of science and technology and the new crusaders of life around abortion, euthanasia and genetic manipulations) to come back again in the field of politics (after September $11^{\text {th }}$ ). 
ци на животот) за повторно да се врати во полето на политиката (после 11-ти септември).

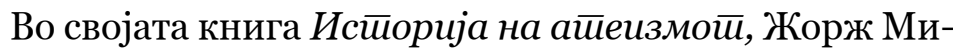
нуа $^{1}$ тврди дека денес имаме 1,8 милијарди агностици и 250 милиони атеисти. Не ми е познато како тој ги добил овие бројки, но тоа е неоспорно - верата веќе не е општествена должност; исто така, факт е дека по 1968 год., сведоци сме на едно брутално отстранување на религиската култура, на целосен прекин при пренесувањето на традицијата меѓу генерациите: сериозно опаѓање на практикувањето на религијата (денес одвај 10\% од Европејците одат в црква повеќето нередовно). Очигледно, тука немаме завера или некаква незгода или случајност, туку би требало да се сетиме на еден епохален факт, кој суштински ја менува човечката цивилизација. Истовремено, религијата (канонизацијата и младинските средби на Папата Јован Павле Втори, аџилакот во Мека) останува единствената традиционална институција, сѐ уште способна да собере милиони луѓе на едно место. Вака или онака, религијата продолжува да го одредува идентитетот, да ги оправдува и образложува чувствата и постапките.

За оној кој има очи да гледа и уши да слуша, уште долго пред 11-ти септември беше очигледно дека е потребно преиспитување на односите помеѓу демократската држава и религијата. Западот бараше (а денес уште повеќе бара) критичко преиспитување на историскиот процес на секуларизација. Всушност, не само што современиот свет не е оној што просветителството го замислуваше - сосем ослободен и независен од религиозни предрасуди: замрзнат во одреден стадиум од човековата еволуција и засекогаш напуштен - туку ги имаме и секуларните слоеви на современата култура кои исто така се вртат кон религијата како кон извор на смисла и на повлас-
In his book History of Atheism Georges Minois ${ }^{1}$ claims we have nowadays 1.8 billion agnostics and 250 million atheists. I do not know how he got these numbers, but it is indisputable - faith is no longer a social duty; it is also a fact that after 1968 we observe a brutal obliteration of religious culture, a full rupture in handing over tradition between the generations - a serious drop in religious practice (today barely 10\% of Europeans go to church - most of them irregularly). Obviously we do not have a conspiracy or some kind of accident or coincidence here, but we ought to think of an epoch-making, fundamentally changing the human civilization fact. At the same time religion (the canonizations and youth meetings of Pope John Paul II, the Mecca pilgrimage) remains the only traditional institution still capable of gathering millions of people at one place. One way or another religion continues to determine the identity, to justify and provide reasons for feelings and actions.

For him who has eyes to see and ears to hear, long before September $11^{\text {th }}$ it was evident that a rethinking of the relations between the democratic state and religion was needed. The West required (and today even more so requires) a critical rethinking of the historical process of secularization. In fact not only is the contemporary world not the one that the Enlightenment imagined - fully free and independent of religious prejudices: frozen at a certain stage of the evolution of mankind and left behind for good - but we have the secular layers of contemporary culture as well turning their face to religions as a source of meaning and privileged positions of basic individual and collective experience that cannot 
тени позиции за основно индивидуално и колективно искуство, кое не може да се замени со секуларни сурогати. Големото враќње на религијата во јавната сфера бара, макар и само од тактички и изборни причини, преиспитување на идејата за секуларна држава, на поделбата меѓу црквата и државата, меѓу јавната и приватната сфера и така натаму. Дури и повеќ од тоа - отаде диктатот на конкретната Realpolitik, присуството на милиони практикувачки верници во Европа денес, кои се често крајно критични кон секуларното западно општество, е доказ не само за религискиот и моралниот плурализам на либералните демократии, туку и претставува причина за испитување на нивните сопствени премиси. Судирот со сосем туѓи облици на живот во последниве годинивојната против теророт, но и катадневниот соживот со значителните имигрантски заедници, исто такаведнаш бараат ваков испит.

Би сакал да се заземам за една „ситуирана“ теологија, „преобрзена“ од судирот со реалноста: теологија адекватна на глобализацијата, видена како радикален раскин со модерноста и нејзините рационални медијации; теологија способна повторно да ги открие изворните значења, земајќи ги нештата од корен. Оваа теологија го има своето потекло во библиската книга на Јов. На прашањето на Јов за она што го истрајал, Бог не дава никакво објаснување - ниту теолошко, ниту социолошко или историско, психолошко, итн. Единствено Неговата химна на создавањето одекнува на крајот. Ова не е само следното продолжение на темата на божјата неодгатливост. Поместувањето на одговорот од едно можно објаснување на несреќата на Јов кон некаква контемплација за создавањето е знак дека не можеме да одгатнеме што се случило. Автентичниот религиски настан, како што тоа го покажа Kјеркегор (Kierkegaard), ја отстранува не само be replaced by secular surrogates. The mighty comeback of religion into the public sphere demands, if only because of tactical and electoral reasons, a rethinking of the idea of the secular state, the division between church and state, between public and private sphere and so on. Even more - beyond the dictate of the concrete Realpolitik the presence of millions of practising believers today in Europe, often extremely critical of the secular western society, is evidence not only for the religious and moral pluralism of the liberal democracies, but also represents a reason for testing their own premises. The collision with fully alien forms of life during the last years - the war on terror, as well as the everyday co-existence with considerable immigrant communities - requires such a test in no time.

I would like to plead for a "situated," "transformed" by the clash with the reality theology: a theology adequate to the globalization, seen as a radical rupture with modernity and its rational mediations; theology capable of rediscovering the initial meanings, taking things up from the roots. This theology finds its origins in the biblical book of Job. To Job's question about what he has endured God does not give any explanation - neither theological, nor sociological, historical, psychological, etc. It is only His hymn of creation that sounds at the end. This is not just the next taking up of the theme of God's impenetrability. Shifting the answer from a possible explanation of Job's misfortune towards a contemplation of the creation is a sign that we cannot "unpuzzle" what has happened. The authentic religious event, as shown by Kierkegaard, takes not only the ethics down, but the reason as well - to push it this way towards another dimension of existence. We can situate it, give it some 
етиката, туку и разумот - за на тој начин да го турне во некаква друга димензија на постоење. Можеме да го ситуираме, да му дадеме некое место од каде што може да биде виден. Ова не е теодикеја, не е оправдување на тоа што се случува, туку попрво е обид да се најде своевидна „ситуирачка“ теологија (во смисла на Адорно (Adorno), но пред него во онаа на Шмит (Schmitt ) и Бенјамин), која, наместо да објаснува, се обидува да ја најде локацијата или точката од каде настанот може да се види, која сака да го ситуира степенот на катастрофата, ако се изразиме со зборовите на Паскал (Pascal).

Модерноста е сцена на судирот меѓу различните традиции: либералната, заснована на рационалниот и работлив поединец, републиканската, која ги има своите основи во граѓанскиот живот, скептичката, со премногу недоверба и сомнеж во индивидуалните илузии и која сѐ им припишува на обичаите и на историјата, марксистичката, која во истоветноста помеѓу човекот и природата го гледа изворот на нашето постоење. Тој конфликт ја одвраќа и спречува модерноста да најде толкување соодветно на нејзините проектирани институции. Денес, сепак, една од традициите преовладува над другите и станува канон: онаа на Хобс (Hobbes), која ги става свеста за смртта и стравот од смртта на почетокот на секое хуманизирање, која се стреми, по секоја цена, да го зачува животот на поединецот и го наоѓ својот излез во договорот, во триумфот на правото над политиката. Биолошката смртност на човекот раѓa различни примери за одложување на неизбежното: наука, економија, безбедност итн. Во последниве години науката за првпат успеа да ги доведе во прашање биолошките граници на човекот и тоа е вклучено во карактеристиките на модерноста, дефинирани од Хобс. Ова е не-прометејска (сѐ уште прилично романтична идеја, која во голема мера се location from where it can be seen. This is not a theodicy, it is not a justification of what is happening, but rather it is an attempt to find some kind of "situating" theology (in the sense of Adorno, but before him the one of Schmitt and Benjamin) which instead of explaining, tries to find the location or the spot from where the event can be seen, which seeks to situate the order of the catastrophe, if we speak in the terms of Pascal.

Modernity is a theatre of the collision between different traditions: the liberal, based on the rational and working individual, the republican one, which has its fundaments in civil life, the sceptic, too mistrustful and suspicious of the individual illusions and which renders all to the habit and the history, the Marxist which sees in the identity between human and nature the source of our being. That conflict prevents and hinders the modernity from finding an interpretation adequate to its projected institutions. Today though, one tradition has overcome the others and become a canon: that of Hobbes which puts death consciousness and the fear of death at the beginning of any humanizing and which, aiming to preserve at any cost the life of the individual, finds its way out of the contract, in the triumph of law over politics. The biological mortality of man gives birth to different instances for delaying the inevitable: science, economy, security, etc. In recent years science has succeeded for the first time to question the biological frontiers of man and this is included in the characteristics of modernity, as defined by Hobbes. That is a non-Promethean (still pretty much a romantic idea, depending to a great extent on transcendence) modernity which finds its roots in the fear of death, which does not seek to replace God, not even to rival him, it just goes on and develops without aiming 
потпира врз трансцедентноста) модерност, која ги наоѓa своите корени во стравот од смртта, која не тежнее да го замени Бог, дури ни да се натпреварува со него, туку само продолжува да се развива без крајна цел. Овој развој произведува само оддолжување, одложување, и ги истиснува смртта и ограниченоста од хоризонтот на модерноста.

Модерноста негира каква и да е однапред зададена реалност, таа се однесува etsi mundus non daretur, таа ниту ја поднесува пасивноста, ниту фактот дека ние доаѓаме после создавањето („Каде беше ти кога ги поставував основите на земјата?“, ${ }^{* 2}$ Бог го праша Јов - ти не си современик или сведок на создавањето, ти дојде по него). Оттаму доаѓа митот за себеконституирачката активност (тоа е токму etsi mundus non daretur, како ништо да не е зададено), односно деконструкцијата на секој возможен свет во корист на потенцијалноста - точката до којашто досега потенцијалот на индивидуата е точката до којашто се простираат неговите закони и права: слободата треба да се разбере како моќ. Модерноста наметнува дека човекот или она нешто што таа го нарекува „човек“ започнува со некаква моќ, онаа да се биде реализиран како смртник. Престрашена од оваа „можност на невозможното“, таа измислува нешта што мораат да го одложат неизбежното: држава, наука, технологија, економија и, зошто да не, религија (таа илузија, според Фројд). Таа е оттука katechon, моќта што одложува, но тоа не е воопшто katechon во јудејска смисла, којшто го одложува Божјиот гнев и, во исто време, го доближува доаѓањето на Месијата. Таa е лош katechon, зашто го одложува доаѓњето на Месијата. ${ }^{3}$

* Во оригиналот станува збор за конструкција која почива на играта на зборови помеѓу именката le lieu (место) и изразот avoir lieu (се случува, се одржува). (заб. на прев.) towards any final goal. This development generates only delay, postponement, pushing away death and limitation from the horizon of modernity.

Modernity denies any preset or pre-given reality, it behaves etsi mundus non daretur, it neither bears passivity, nor the fact that we come after the creation ("Where were you when I laid the earth's foundation?,"2 God is asking Job - you are not a contemporary or witness of creation, you came after it). Hence the myth of the selfconstituting activity (that is precisely etsi mundus non daretur, as if nothing is given), that is the deconstruction of any possible world in favour of potentiality - the point up to which the potential of the individual stretches is the point up to which his law and rights are spreading: freedom is to be understood as power. It imposes that the human or that thing which it calls "human" starts with a power, which is to be realized as mortal. Terrified by this "possibility of the impossible," it invents instances that have to delay the inevitable: state, science, technology, economy and why not religion (this illusion according to Freud). That is therefore a katechon, the power that delays; but it is not katechon at all in the Judaic sense, which delays God's anger and at the same time brings Messiah's advent forward. It is a bad katechon because it delays the advent of the Messiah. ${ }^{3}$ 
Модерноста настојува да се дефинира себеси како бесконечност во конечното. Тоа нема ништо заедничко со начинот на кој смртта и конечноста се промислени во претходните култури кои ги вклучуваат смртните луѓе во големиот синџир на постоењето: од бесмртните богови сѐ до безживотните нешта, минувајќи преку исто така животните. Смртноста во традиционалната култура не е биолошка, таа укажува на човековата положба во космосот, неговиот статус во однос на боговите и на останатите суштества. Јудео-христијанската конечност најсуштински ја разоткрива зависноста на создавањето, кое нема свое сопствено битие, туку го има својот Бог Создател, преку кој, според Св. Павле, „живееме, и се движиме и постоиме“. ${ }^{4}$

Како да продолжиме со карактеризирање на оваа модерност? Не постои никаков податок и светот дури се чини како резултат на технолошко производство. Самиот живот повеќе не е биос. Древните народи правеле разлика меѓу биос и зое: првиот всушност го претставува човековиот живот, кој бил дефиниран од целите, нормите на соживот и однесување, ритуалите итн. Таков бил, на пример, животот на занаетчијата, граѓанинот или философот и тој бил соодветно дефиниран, како што тоа го покажа Хана Арент, како активен или контемплативен живот. Зое, пак, бил чисто органскиот процес на живот. Денес биос станува зое, производот на биотехнологиите. Се покажува дека модерноста е без свет, како и без човечко битие: човекот е на договор или конвенција. Моќта на поединецот (денес наречена човекови права) е, како што е покажано погоре, potenita sui, таа ги произведува, во согласност со приликата и со можностите на технологијата, овие реалности кои ние ги нарекуваме човечки живот или свет. Ништо вистински не ѝ претходи на оваа производствена моќ. Динамиката на модерноста, којашто Фуко ја нарекува био-моќ, се
Modernity strives to define itself as infinity in the finite. That has nothing to do with the way death and finitude are thought of in the preceding cultures which include mortal people in the big chain of being: from the immortal gods up to the inanimate things, going through the animals as well. Mortality in traditional culture is not biological, it points to man's position in the cosmos, his status in relation to gods and the rest of the creatures. The Judeo-Christian finitude reveals most essentially the dependence of creation, which does not possess its own being, but has it in its God the Creator in whom, according to St. Paul, "we live and move and have our being."4

How should we go on characterizing this modernity? There is no datum and the world even appears to be the result of technological production. Life itself is not bios anymore. The ancients made a difference between bios and zoe: the former actually represents human life, which was defined by the goals, the norms of co-existence and behaviour, the rituals, etc. Such was, for instance, the life of the craftsman, the citizen or the philosopher and it was accordingly defined, as shown by Hannah Arendt, as an active or contemplative life. Zoe, this was the purely organic process of life. Today bios becomes zoe, the product of biotechnologies. Modernity turns out to be without a world as well as without a human being: human is a result of agreement or convention. The power of the individual (called human rights nowadays) is, as shown above, potenita sui, it produces, according to the occasion and the possibilities of technology, these realities that we call human life or world. Nothing truly precedes this productive power. The dynamics of modernity, which Foucault calls bio-power, extend up to the point where the potential of the individual is extending in the horizon of death. In other words, it commands life and 
протега до точката во која потенцијалот на единката се проширува во хоризонтот на смртта. Со други зборови, таа заповеда со животот и смртта, преземајќи го правото да ги преобрази, претворајќи ги едноставно во предмет на конвенција.

Библиската теорија за создавањето ја покажува пред сѐ онтолошката зависност на битието во самиот чин на неговото постоење. Битието самото по себе е ништо, тоа ја нема во себе својата онтолошка стварност, и тоа е секогаш под прашање. Нема сомнение дека битието постои и дека е цврсто закотвено во своето постоење, но, истовремено, тоа е под радикален притисок на ништожноста, во смисла дека не го носи во себе своето оправдување. Концептот за причина тука е мошне сиромашен, а концептот за релација најдобро ја изразува тешкотијата на разликување помеѓу создаденото и не-создаденото во рамките на западната онтологија. Онтолошкиот статус на создаденото е одреден од концепцијата на релација, иако таа е најслабо развиена во целата метафизика. Битието е создадено сѐ додека се потпира на Бог. Создавањето не е премин од ништожност кон битие, тоа нема два спротиставени термина, туку во своето битие-ништо реферира на несоздаденото. Оваа зависност ги воспоставува конечноста и границите на битието, но таа не очајува. Таа не посочува некаква должност, ниту доминација или зависност (ние не постоиме заради некоја компулсивна или принудна релација, каде Бог ја уништува својата творба), таа ѝ дава израз на слободната великодушност на Најмилостивиот: обдарена со дарот на животот и со милост која не отфрла ништо од тоа што е. Дарежливост, која прави Бог дури и да го сподели нашиот живот.

Ако е така, тогаш само Бог го поседува чинот да се биде. Добро знаеме дека „јас сум“ е Неговото име. Создавањето, оттука, не е одговорот на прашањето death, assuming the right to transform them, turning them simply into an object of convention.

The biblical theory of creation shows at first place the ontological dependence of being in the sole act of its being. Being by itself is nothing, it does not have in itself its ontological actuality, and it is always under question. No doubt being exists and is heavily anchored in its being but at the same time it is radically affected by nothingness in the sense that it does not bear in itself its justification. The concept of cause here is rather poor and the concept of relation expresses best the difficulty of differentiating between created and non-created within the framework of western ontology. The ontological status of the created is defined by the conception of relation even though it is most feebly developed in the whole metaphysics. Being is created as far as it relies on God. Creation is not a transition from nothingness into being, it does not have two opposite terms but in its being-nothing it refers to the uncreated. This dependence lays down the finitude and the limits of existence, but it does not despair. It does not point to any duty, neither dominance nor dependence (we do not exist because of some compulsive or forceful relation, where God annihilates its creation), it gives expression to the free generosity of the Most Gracious: endowing with the gift of life and with grace which does not reject any of that which is. Generosity that leads God even to share our life.

If that, then God only possesses the act to be. We know well that "I am" is His name. Creation, consequently, is not the answer to the question that bothers modern 
што толку ја мачи модерната западна метафизика: „Зошто има битие, а не пак ништо?“ Создавањето не е одговор за задоволување на неуморниот дух соочен со енигматичното присуство на светот. Таму не наоѓаме олеснување за сопствените стравови, ниту за стравопочитта поради крајот. Соочен со недофатливата мистерија на „јас сум“ верникот не прашува: „Но Ти, зошто си Ти?“ Тој само би можел да каже, претпоставувајќи од својата позиција: „Увидувам дека Ти си единствениот и го прифаќам светот и животот како твој дар, зашто Ти си.“"Или со зборовите на Јов: „Бев слушал за Тебе со слухот на увото; сега, пак, очите мои те гледаат“. ${ }^{5}$

Да се навратиме сега на прашањето: колку вреди сево ова по 11-ти септември? Зарем не се соочуваме со идеологијата на терористите, модерна по своите средства, но архаична по своите мотиви, без некаква вистинска врска со погоре дефинираната модерност? Мене, сепак, ми се чини дека анализата на тероризмот како политичка религија или како политика издигната на ранг на религија не го опишува проблемот суштински. Теророт чии престрашени сведоци бевме сите во последните години е нем, тој нема што да му каже на непријателот, на другиот, тој дури не сака ниту да го преобрати во својата вера, само сака да го уништи, целосно и сосема. Интензивното и смртоносно непријателство што еден терористички чин го содржи, е израз на одредена „политика“ (во термините на Карл Шмит) која не значи ништо, на која ѝ недостига внатрешната моќ за да им стави крај на насилството и немирот, да стави ред во хаосот, која не дефинира никакви вистински граници помеѓу цивилизациите, туку е само злокобно остварување на некои проектирани фантазми. Богохулна анти-мудрост (да се сетиме на Мудроста, поставена веднаш до Бога во Книгайа Мудросии Соломонова) која прогласува одредени битија за ништовни, дека тие всушност western metaphysics so much: "Why is there being and not rather nothing?" Creation is not an answer to content the restless spirit facing the enigmatic presence of the world. We do not find a relief there for our own fears and awe of the end as well. Facing the fathomless mystery of "I am" the believer does not ask: "But You, why are You?" He could only say, assuming from his position: "I recognize that You are the only one and I accept the world and life as your gift, because You are." Or in Job's words, "My ears had heard of you but now my eyes have seen you." 5

Let's go back now to the question: what is all this worth after September $11^{\text {th }}$ ? Aren't we facing the ideology of the terrorists, modern in its means, but archaic in its motives, without any real connection to the defined above modernity? It seems to me though that the analysis of terrorism as a political religion or as a policy raised to the rank of religion does not fundamentally describe the problem. The terror of which we were all terrified witnesses during the last years is dumb, it does not have anything to say to the enemy, to the other, it does not even seek to convert him to its faith; it only wants to destroy him, totally and completely. The intensive and deadly hostility, which a terrorist act contains, is an expression of a certain "policy" (in the terms of Carl Schmitt) that does not mean anything, that misses the inner power to put an end to violence and unrest, to put order into chaos, that does not define any real borders between civilizations but is simply the sinister realization of some projected phantasms. A blasphemous anti-wisdom (let us remember Wisdom, seated next to God in The Book of Wisdom) which declares certain beings are nothing, that they actually do bear nothing in themselves and simply must return to nothing. Supreme sacrilege, which usurps God's might: that is - to be no more, no more Christians 
не носат ништо во себе и едноставно мора да се вратат кон ништо. Врвно сквернавење, кое ја узурпира величината на Бог: а тоа е - да нема веќе, да нема веќе христијани и особено Евреи во исламските земји, да го нема веќе Израел. Токму оваа уништувачка и себеистребувачка моќ ја сочинува врската помеѓу гореспоменатата верзија на модерноста во која битието е производ на програмата на сопствената моќ, а не создание на Највисокото Добро кое создава разлика.

Гинтер Андерс (Günther Anders) тврди дека можеме да ја опишеме нашата ера само со теолошка терминологија. Она што го имам на ум, се чини дека вели тој, е дека метаморфозата е толку фундаментална што таа веќе не може да се карактеризира со поинакви концепти освен со теолошки... Со помош на машините, создадени од нас, станавме како богови. Без сомнение, боголики сме во строго негативна смисла, бидејќи ние не зборуваме за creatio ex nihilo, туку многу повеќе за тоа дека сме целосно способни за тотален reductio ad nihil. Мислам дека овие размислувања на Андерс, предизвикани од атомската бомба, мошне точно ја опишуваат нашата ситуација. Глобалниот тероризам е еден од модалитетите на оваа уништувачка семоќ која сите сакаат да ја поседуваат. Постојат и други: биотехнологиите, кои произведуваат живот (зое) како да е тоа некаква стока, некое добро. Не сме дури ни во позицијата ниту пријавуваме право на живот и смрт; ние слегуваме уште подолу, долу до битието, заедничката основа на животот и смртта. Го преобразуваме битието, не во релација, туку во производ.

Книгата на Мудроста Соломонова добро ја опишува врската меѓу негирањето на создавањето и идолатријата: оние кои тврдат дека „ниту тие биле од почетокот“ и „ниту ќе бидат довека“, наликуваат на занаетчијата кој, работејќи на некое инаку корисно and especially Jews in the Islamic countries, Israel no more. It is exactly this destructive and self-annihilating power that makes the connection to the above-mentioned version of modernity in which being is a product of the programme of the own power and not a creation of the Highest Good that creates difference.

Günther Anders claims that we can describe our own era with theological terminology only. What I have in mind is, he seems to say, that the metamorphosis is so fundamental that it cannot be characterized by anything other than theological concepts... With the help of machines, created by us, we became like gods. No doubt we are God-like in a strictly negative sense because we are not speaking of creatio ex nihilo but much more that we are fully able of a total reductio ad nihil. I think these reflections of Anders, triggered by the atom bomb, describe our situation rather precisely. Global terrorism is one of the modalities of this annihilating omnipotence that everyone seeks to possess. There are others as well: biotechnologies, which produce life (zoe) as if it were some merchandise. We are not even in the position or register of having the right of life and death; we are descending even further, down to being, the common base of life and death. We are transforming being not into a relation but into a product.

The Book of Wisdom describes well the connection between the denial of creation and idolatry: the ones who claim that "neither were they from the beginning" and "neither shall they be forever" look like the craftsman who working on an otherwise useful thing actually produces 
нешто, всушност произведува идол, или на родителот кој, мачен од смртта на своето дете, создава негова слика и почнува да ја обожува како да е бог, или пак на деспотот кој создава некаква слика на себеси со цел да го осигура своето присуство на целата своја територија, за да ги искуши своите поданици и да ја придобие нивната почит. ${ }^{6}$ Светото Писмо сепак вели: Бог не ја создаде смртта... „Бог го создаде човекот за

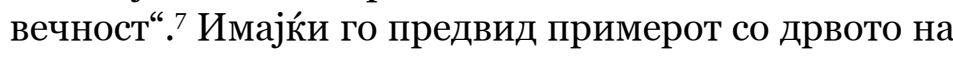
занаетчијата кое станало идол, Библијата непосредно ја покажува врската меѓу смртта, моќта и идолатријата. Бог Создател не произведува идоли, туку ја контемплира, ја вкусува добрината на создаденото ${ }^{8}$ и потоа мирува. Идолопоклоникот, напротив, е занаетчија кој потполно го отуѓува она што го создал. Кон добро познатите прилагодувања кон созданието - бунтот, недостатокот на разбирање, покорноста, чувството на бидување ништо (ништожноста на созданието, мислена од мистиците) - модерноста го додава исто и срамой од човековата конечност. За да ги избегнеме смртта и срамот (бидејќи создавањето нам веќе ни значи само смрт) го наоѓаме едното и единствено компензациско решение: да го забрзаме градењето на џиновскиот артефакт, кој ги содржи сите нешта, вклучително човекот, преку луд и жесток инженеринг. Мораме да го сместиме ова решение во неговиот природен поредок: оној на идолатриското анти-создавање, а не само на технолошката трансформација.

Ситуирањето на енигматичната посебност на модерноста секако не ја исцрпува целосно задачата на философијата денес. Но мислам дека таа би требала токму тука да почне, за да продолжи во потрагата по условите и патиштата на автентичното човечко постоење. an idol or like the parent tormented by the death of his child creates an image of it and starts worshipping it like a god or like the despot who makes some kind of image of himself in order to ensure his presence all over his territory and to tempt his subjects and win their respect. ${ }^{6}$ The Scripture says though: God did not create death ... "God created man to be immortal." Given the example of the craftsman's wood that became an idol the Bible shows directly the connections between death, power and idolatry. God the Creator does not produce idols, but contemplates, tastes the goodness of the created $^{8}$ and then rests. The worshipper of idols on the contrary is a craftsman who alienates fully what he has created. To the well-known adjustments towards the creation the rebellion, the lack of understanding, the obedience, the feeling of being nothing (the nothingness of creation, thought by the mystics) - modernity adds the shame of man's finiteness as well. To avoid death and shame (because the creation means already only death to us) we find the one and only compensatory solution: to speed up the building of the giant artefact, containing all things, including man, in a mad and furious engineering. We have to situate this solution in its innate order: the one of the idolatrous anti-creation and not just technological transformation.

Situating the enigmatic peculiarity of modernity certainly does not altogether exhaust the task of philosophy today. But I think it should start right here to continue seeking the conditions and ways of authentic human existence. 
Белешки:

1. Georges Minois, Histoire de l'atheisme (Paris: Fayard, 1998).

2. Јов 38: 4 .

3. Овој есхатолошки концепт се појавува во прилично енигматичниот пасус од 2. Сол.: „Никој да не ве измами ни по каков начин; оти оној ден нема да настапи додека најнапред не дојде отпаѓањето и не се открие човекот на гревот, синот на погибелта, кој што се противи и се превознесува над сѐ, што се наречува Бог или светост, за да седне како бог во Божјиот храм, покажувајќи се дека е Бог. Не помните ли дека, уште кога бев при вас, ви зборував за тоа? И сега знаете што Го задржа Него да се открие во Свое време. Тајната на беззаконието веќе дејствува, само тоа нема да биде извршено, додека не се отргне оној, што ја задржува сега; тогаш ќе се открие и беззаконикот, кого што Господ Исус ќе го убие со здивот на устата Своја, и преку блесокот на Своето доаѓњње ќе го истреби оној, чие јавување, по дејството на сатаната, е со секаква сила и знаци и лажни чудеса, и со секакво неправедно измамување меѓу оние, кои загинуваат, затоа што не ја примиле љубовта на вистината за своето спасение.“(2. Сол. 2:3-10). Кайехон значи „оној што се воздржува“, но и оној „што ја задржува“ тајната на беззаконието, кој го спречува доаѓањето на Антихристот и крајот на времето. Задачата на овој текст најверојатно била да ги примири оние што со страст го чекале Судниот ден, за кој апостолот инспирирано пишува во 1. Сол. Но копнежот по крајот на светот кој се ближи ги возбуди душите: некои ја изгубија дисциплината, прекинаа да работат и да се грижат са своите семејства - тие само чекаа. Заради ова во неговото следно послание до Солунјаните апостолот истакнува дека Божјиот ден ќе „се открие во Свое време“ и ќе биде претходен од „обратните“ претскажувања на издигањето на беззаконикот на Божјиот трон. Сепак, во тој ист миг на привиден триумф на злото ќе се случи разврска, ќе се случи
Notes:

1. Georges Minois, Histoire de l'atheisme (Paris: Fayard, 1998).

2. Job 38: 4 .

3. This eschatological concept appears in a rather enigmatic passage of 2 Thessalonians: "Don't let anyone deceive you in any way, for that day will not come, until the rebellion occurs and the man of lawlessness is revealed, the man doomed to destruction. He will oppose and will exalt himself over everything that is called God or is worshipped, so that he sets himself up in God's temple, proclaiming himself to be God. Don't you remember that when I was with you I used to tell you these things? And now you know what is holding him back (to katechon), so that he may be revealed at the proper time. For the secret power of lawlessness is already at work; but the one who now holds it back (katechon) will continue to do so till he is taken out of the way. And then the lawless one will be revealed whom the Lord Jesus will overthrow with the breath of his mouth and destroy by the splendor of his coming. The coming of the lawless one will be in accordance with the work of Satan displayed in all kinds of counterfeit miracles, signs and wonders, and in every sort of evil that deceives those who are perishing. They perish because they refused to love the truth and so be saved." (2 Thessalonians 2:3-10). Katechon means the "one that holds back", but also the one "who delays" the secret of lawlessness, who hinders the coming of the Antichrist and the end of times. The task of this text was most probably to calm down the passionately awaiting the inevitable Doomsday, about which the apostle writes inspired in the 1 Thessalonians. But the longing for the approaching end of the world stirred the souls: some loosed the discipline, stopped working and taking care of their families - they were just waiting. That is why in his next epistle to the Thessalonians the apostle points out that the day of God will be "revealed at the proper time" and will be preceded by the "reversed" omens of the rise of the lawless up to God's throne. In that same moment though 
Божјиот ден. Оттаму е потребата од потпирање врз оној кој го задржува победничкиот потег на Антихристот и на тој начин ги организира и им дава значење на настаните.

4. Дела 17: 28.

5. Јов 42: 5 .

6. Види Мудр. Сол. 14: 13-17.

7. Мудр. Сол. 2: 23.

8. „И виде Бог дека е добро“, Битие 1: 9. of apparent triumph of evil a denouement will happen, God's day will happen. Hence the need to rely on the one that holds back the victorious move of the Antichrist and in this way organizes and gives a meaning to the events.

4. Acts 17: 28.

5. Job 42: 5 .

6. Cf. The Book of Wisdom 14: 13-17.

7. Wisdom 2: 23.

8. "And God saw that it was good," Gen 1: 9. 